\title{
PEMIKIRAN FILSAFAT AL-FARABI DAN IBNU SINA
}

\author{
Andri Ardiansyah \\ Email: andre.andriansyah2015@gmail.com
}

\begin{abstract}
Abstrak
Eksistensi dua filosof ternama dunia yakni Al-Farabi dan Ibnu Sina termasuk yang membawa tonggak-tonggak filsafat Islam yang kemudian diikuti oleh para filosof setelahnya. Dari karya-karya merekalah sehingga membuat dunia tercerahkan baik dalam bidang kedokteran maupun dalam bidang keilmuan yang lain seperti filsafat emanasi dan jiwa yang telah penulis sebutkan dalam pembahasan tersebut. Al-Farabi dan Ibnu Sina menjadi ujung tombak bagi generasi Islam setelahnya, dari merekalah generasi Islam belajar banyak hal tentang filsafat Islam. Sekalipun masih banyak yang diperdebatkan oleh para ulama dan generasi Islam tentang isi pikiran-pikiran kedua filosof tersebut. Tetapi pada dasarnya mereka telah memberikan kontribusi yang terbaik lewat keilmuan-keilmuannya pada Islam khususnya dan dunia luar pada umumnya. Misalnya konsen pemikiran filsafat emanasi Al-Farabi dan Ibnu Sina yang memilki kesamaan terkait dengan konsepsi emanasi dari akal ke 1 sampai akal ke 10 yang menekankan bahwa hanya Tuhan saja yang ada dengan sendiri-Nya tanpa sebab dari luar diri-Nya, dan karena itu ia sebut Waajib al-Wujuud li zaatih, (yang mesti ada karena diri-Nya sendiri). Dari-Nya memancar segenap alam ciptaan-Nya, baik yang bersifat rohani (imateri) maupun yang bersifat jasmani (materi).
\end{abstract}

Kata Kunci: Pemikiran Filsafat, Al-Farabi, Ibnu Sina

\section{Pendahuluan}

erkembangan pemikiran filsafat Islam dalam mengkaji pengetahuan
sesungguhnya tidak terlepas darai sumbasi pemikiran dua tokoh filsafat Islam
pada masanya yakni Alfarabi dan Ibnu Sina. Kedua tokoh inilah yang juga disinyalir mengilhami masa pencerahan peradaban Eropa terutama dari segi ilmu pengetahuan sains sehigga menjadi peradaban yang cukup maju hingga saat ini. Bila dilihat dari sisi riwayat hidup, Al-Farabi (lengkapnya, Abu Nasr Muhammad Ibnu Muhammad Ibnu Uzlag Ibnu Turkhan al-Farabi, hidup pada (295-339 H/ 872-950 M). Kendati ia dipandang sebagai bintang terkemuka dikalangan filosof Muslim, informasi tentang dirinya sangat terbatas. Umunya para penulis sejarah menyatakan bahwa Al-Farabi itu orang Turki (ayah dan ibunya Orang Turki), tapi Ibnu Abi 
Usaibi'ah menyebutkan bahwa ayahnya, seorang jenderal perang Persia. ${ }^{1}$ Al-Qadhi Sho'id Ibnu Ahmad Al-Andalusi dalam bukunya Thobaqaat-al-Umam, menyebutkan dua nama bagi Al-Farabi dalam bab yang berbeda, yang pertama, Abu Nashr Muhammad Ibn Muhammad Ibn Nashr dan yang kedua, Abu Nashr Muhammad ibn Nashr. $^{2}$

Al-Farabi lahir di desa Wasij, dekat atau dalam negeri Farab, di selatan Samarkand, Asia Tengah. Menurut suatu informasi, ia pada masanya telah hijrah bersama orang tuanya ke Bagdad, tapi menurut informasi lain, ia telah bekerja sebagai hakim dan kemudian baru berada di Bagdad pada usia 50 tahun atau pada usia 40 tahun. Tidak di ketahui apakah al-Farabi telah mengalami perkembangan pesat dalam studinya di Farab, tapi tidak diragukan lagi bahwa di Bagdad ia memperoleh kematangan maksimal. Ia berada di pusat ilmu dan peradaban klasik Islam sampai ia berumur 70 tahun. Di sana ia dapat berdiskusi dan saling mengambil manfaat dengan banyak ahli dalam berbagai bidang. Paling kurang ia berada di Bagdad selama 20 tahun, dan dalam selang masa itu ia pernah juga pergi ke Harran, yang sejak sebelum masa Islam dikenal sebagai salah satu pusat studi ilmu dan falsafat. Dari Harran ia kembali ke Bagdad. ${ }^{3}$

Al-Farabi meninggalkan Bagdad untuk selamanya setelah Jenderal Tusun dari Dailam memasuki Bagdad dan membunuh Khalifah Muttaqi pada tahun 329 H/940 M. Ia bermukim sebentar di Damaskus dan kemudian terus ke Aleppo. Konon ia juga pernah pergi ke Mesir, yang menurut satu informasi dilakukannya sebelum ia pergi ke Aleppo, tapi menurut informasi lain dilakukannya lebih kurang satu tahun sebelum ia wafat. Sisa usia 10 tahun setelah meninggalkan Bagdad, lebih banyak dihabiskannya di Aleppo. Di kota itu ia menjadi bintang terkemuka di tengah-tengah banyak ahli dalam berbagai bidang, yang menghiasi istana Amir Saif al-Daulah. Al-Farabi hidup sangat sederhana kendati Amir Saif al-Daulah sangat baik kepadanya dan mau menjamin biaya hidupnya dengan uang ynag berlimpah. Ia merasa cukup mengambil empat dirham saja setiap hari untuk memenuhi kebutuhan hidupnya sebagai filosof yang zahid. Persahabatannya dengan Amir Saif al-Daulah demikian baik sehingga ia ikut mendampingi Amir itu dalam perjalanan ke Damaskus pada tahun 339 H/950 M. Di Damaskus itulah Al-Farabi wafat dalam usia 80 tahun dan dikuburkan di sana. ${ }^{4}$

\footnotetext{
${ }^{1}$ Ahmad Fuad Al-Ahwani.Filsafat Islam, (Jakarta: Pustaka Firdaus, 1997), 74.

${ }^{2}$ Sa'id Zayid.Abu Nashr Al-Farabi: Fi al-Dzikra al-Fiah li Wafaatih, (Kairo: al-Hai'ah alMishriyah al-'Ammah li al-Kitab, 1993), 148

${ }^{3}$ Harun Nasution.Filsafat dan Mistisisme Dalam Islam, (Cet. II; Jakarta: Bulan Bintang, 1978), 26.

${ }^{4}$ Abdul Aziz Dahlan. Pemikiran Falsafi Dalam Islam, (Jakarta: Karya Unipress, 2003), 59.
} 
Selain Al-Farabi, tokoh filsafat muslim yang juga memiliki pengaruh dalam kajian filsafanya yakni Ibnu Sina termasuk filosof muslim yang mengembangkan falsafat klasik Islam ke puncak tertinggi. Nama lengkapnya Abu Ali al-Husayn Ibnu 'Abdillah Ibnu Sina (hidup dari tahun 370 H/980 M sampai tahun 428 H/1036 M). Ia lahir di desa Afsyanah dekat Bukhara, wafat dan berkubur di Hamadan. ${ }^{5}$ Selain telah hafal Al-Qur'an seluruhnya dalam usia 10 tahun, ia dalam usia lebih kurang 17 tahun telah menguasai dengan baik ilmu-ilmu dan falsafat yang berkembang di masanya. Dengan membaca sendiri buku-buku kedokteran selama satu tahun, ia sudah dapat tampil sebagai dokter pada usia 17 tahun itu dan berhasil menyembuhkan penyakit Sultan Bukhara, Nuh Ibnu Mansyur, dari Dinasti Samaniah, sejak itu ia menjadi dokter istana dan dapat leluasa memasuki perpustakaan istana di Bukahara. Dari bahan-bahan yang tersedia, dapat dirangkum bahwa Ibnu Sina hidup di Afsyanah sampai usia 5 tahun, di Bukhara sampai usia 21 tahun, di Kurkang sampai usia 32 tahun, di Jurjan sampai usia 35 tahun, di Hamadan sampai usia 44 tahun, dan di Isfahan sampai usia 58 tahun. Pada usia 58 tahun itulah ia dalam kondisi sakit menyertai perjalanan Amir Alauddin ke Hamadan, wafat dan berkubur disana. Karena kejeniusannya, ia dapat melaksanakan banyak tugas: praktik pengobatan, mengajar mengarang, menjadi penasehat politik, dan bahkan menjadi wazir. Ia menjalankan praktik pengobatan sejak usia 17 tahun, mengarang sejak usia 21 tahun, menjadi wazir (menteri) di Hamadan lebih kurang 9 tahun, dan menjadi penasehat politik di Isfahan selama lebih kurang 14 tahun. Sebagai pengakuan atas kematangannya dalam ilmu pengetahuan dan falsafat dan atas kepemimpinannya dalam bidang politik, ia dikenal dengan gelar Al-Syaykh al-Ra'is. ${ }^{6}$

\section{Menelaah Konsep Dasar Pemikiran Filsafat Al-Farabi}

\section{Tuhan dan Sifat-Sifat-Nya}

Al-Farabi dalam risalahnya tentang politik, ${ }^{7}$ menyatakan bahwa upaya pertama yang harus dilakukan seseorang ialah mengetahui adanya pencipta bagi alam dengan segala bagiannya, melalui pengamatan terhadap segala yang maujud ini dengan mempertanyakan apakah masing-masing bagian maujud ini memiliki sebab atau bukan. Melalui upaya induksi, orang akan mengetahui bahwa ada sebab bagi tiap sesuatu. Kemudian, kata Al-Farabi, hendaklah orang itu

\footnotetext{
${ }^{5}$ Hadi Suprapto. "Al-Farabi dan Ibnu Sina: Kajian Filsafat Emanasi dan Jiwa Dengan Pendekatan Psikologi”, (Jurnal Al-Hadi, Vol. 2, No. 2, Januari-Juni 2017), 446.

${ }^{6}$ Abdullah Nur, Ibnu Sina: Pemikiran Filsafatnya Tentang Al-Fayd, Al-Nafs, An-Nubuwwah, dan Al-Wujud, (Journal Hunafa, Vol. 6, No. 1, April 2009), 105-106.

${ }^{7}$ Imam Sukardi. Disertasi Pemikiran Politik Al-Farabi (Diskursus Kepemimpinan Negara), (Jakarta:Disertasi, UIN Syarif Hidayatullah Jakarta, 2008), 130-131.
} 
memperhatikan sebab-sebab yang dekat, dan mempertanyakan apakah rangkaian sebab-sebab itu akan berlanjut tanpa akhir atau sebaliknya. Adalah mustahil, kata Al-Farabi, bahwa sebab-sebab itu berlanjut tanpa akhir karena apa yang tak berakhir tidak bisa diketahui (dipahami). Sekiranya A menjadi sebab bagi B, B menjadi sebab bagi $\mathrm{C}$, dan $\mathrm{C}$ menjadi sebab bagi $\mathrm{A}$, maka itu berarti bahwa $\mathrm{A}$ menjadi sebab bagi dirinya, dan hal itu mustahil, kata Al-Farabi. Jadi, sebabsebab itu mestilah ada akhirnya, dan sebab paling akhir dari sebab yang banyak itu adalah Yang Maha Esa (Al-Wahid). Sebab dari segala sebab pastilah ada dan Esa; itulah Tuhan Yang Maha Esa.

Jalan terbaik bagi kita, kata Al-Farabi, untuk menunjukkan sifat-sifat Yang Maha Esa itu adalah juga mengamati fenomena yang ada disekitar kita. Dari fenomena itu kita menjumpai dua kenyataan: yang utama dan yang hina. Maka yang lebih pantas untuk kita sandangkan kepada Yang Maha Esa adalah sifat yang paling utama. Kita tahu bahwa sebutan "yang ada" (al-mawjuud) lebih mulia dari sebutan "yang tidak ada" (al-ma'dum), maka haruslah kita katakan bahwa ia ada (maujud). Kita juga tahu bahwa "yang hidup" lebih utama dari "yang tidak hidup", maka hendaklah kita katakan bahwa ia itu hidup. Kitapun tahu bahwa "yang tahu" lebih utama dari "yang tidak tahu", maka hendaklah kita katakan bahwa ia mengetahui. Begitulah caranya kita menghubungkan semua sifat-sifat kepada Tuhan Yang Maha Esa,dengan disertai keinsafan bahwa ia pada hakikatnya Mahasuci dari menyerupai sifat-sifat utama, lebih mulia, lebih tinggi dari pada apa yang dapat dibayangkan manusia, dan tidaklah tersedia jalan bagi siapapun untuk mengetahui-Nya sebagaimana ada-Nya. ${ }^{8}$

Tuhan Yang Maha Esa itu, menurut Al-Farabi, maha sempurna, bersih dari segala macam kekurangan, dan suci dari sebab-sebab, seperti sebab-materi, sebab bentuk, sebab pelaku, dan sebab tujuan. Ia bukanlah materi dan karena itu pada hakikatnya Ia adalah akal aktual ( $a l$ - 'aql bi al-fi'l); Ia memikirkan (ber-ta'aqqul terhadap) diri-Nya, maka ia adalah akal, aktivitas memikir, dan yang dipikirkan sekaligus secara aktual (al- 'aql wa al-'aqli wa al-ma'qul bi al-fi'l). Selanjutnya Al-Farabi menegaskan bahwa Tuhan, yang disebutnya juga Pencipta Maha Agung (Al-Bari Jalla Jalaaluh) adalah pengatur sekalian alam, dan tidaklah tersembunyi dari-Nya sesuatu kendati sekali debu, dan tak satupun dari bagian alam ini luput dari perhatian ('inayah)-Nya.

\footnotetext{
${ }^{8}$ M. Wiyono, Pemikiran Filsafat Al-Farabi (Journal Substantia, Vol. 18, No. 1, April 2016), 67.
} 


\section{Penciptaan Alam Secara Emanasi}

Berbeda dengan Al-Kindi yang berpandangan bahwa alam semesta ini diciptakan Tuhan dari tidak ada (creation ex nihilo) menjadi ada, Al-Farabi cenderung memahami penciptaan alam oleh Tuhan melalui proses emanasi sejak zaman azali sehingga tergambar bahwa penciptaan alam oleh Tuhan bukan dari tidak ada menjadi ada. Menurut Al-Farabi, hanya Tuhan saja yang ada dengan sendiri-Nya tanpa sebab dari luar diri-Nya, dan karena itu ia sebut Waajib alWujuud li zaatih, (yang mesti ada karena diri-Nya sendiri). Dari-Nya memancar segenap alam ciptaan-Nya, baik yang bersifat rohani (imateri) maupun yang bersifat jasmani (materi). Segenap alam tidaklah ada dengan sendirinya, tapi akan karena sebab diciptakan/dipancarkan oleh Tuhan. Oleh karena itu Al-Farabi menyebut alam itu mukmin al-wujuud li zaatih, wajib al-wujuud li gayrih (boleh ada dilihat dari dirinya, mesti ada karena sebab diluar dirinya). Pancaran (emanasi) alam dari Tuhan terjadi sebagai akibat aktivitas Tuhan memikirkan (ber-ta'aqqul terhadap) diri-Nya. Aktivitas memkirkan itu menjadi sebab bagi pemancaran segenap alam ciptaan-Nya, seperti pemancaran sinar dari matahari.

Berpegang pada konsep ilmiah masa lalu, Al-Farabi memahami alam semesta yang bersifat fisik terdiri dari sembilan lapis lingkaran langit, dimana lingkaran suatu langit berada di dalam lingkaran langit yang lebih besar (luas), sedang bumi ini berada pada pusat kesembilan lingkaran langit itu. Jadi ada sepuluh bagian alam semesta yang bersifat fisik: satu bumi dan sembilan langit. Dari Al-Qur'an orang di masa Al-Farabi juga bisa memahami alam semesta yang bersifat fisik ini terdiri dari bumi, tujuh langit, kursi, dan 'arasy; jumlahnya 10 bagian juga. Tuhan mengendalikan kesepuluh bagian alam itu, tidak langsung, tetapi melalui 10 akal. Kesepuluh akal itu pun mengendalikan kesepuluh bagian alam itu melelui jiwa bagian alam masing-masing. Yang langsung mengendalikan masing-masing dari kesepuluh bagian alam itu adalah jiwa masing-masing. ${ }^{9}$

Dengan mengembangkan teori emanasi Plotinus, Al-Farabi menghasilkan teori emanasi, yang dapat diungkapkan sebagai berikut. Tuhan (yakni Wujud I), karena memikirkan diri-Nya, memancarkan Akal I (Wujud II). Akal I, karena memikirkan Tuhan, memancarkan akal II (Wujud III), dan, karena memikirkan dirinya sendiri, memancarkan lingkaran langit pertama (al-samaa al-uula), yakni langit terbesar/terluas dan terjauh dari bumi. Akal II, karena memikirkan Tuhan, memancarkan Akal III (wujud IV), dan, karena memikirkan dirinya sendiri, memancarkan lingkaran langit kedua yang penuh dengan bintang-bintang tetap

\footnotetext{
${ }^{9}$ Abdul Aziz Dahlan. Pemikiran Falsafi Dalam Islam, (Jakarta: Karya Unipress, 2003), 64.
} 
(al-kawaakib al-saabitah). Akal III, karena memikirkan Tuhan, memancarkan Akal IV (wujud V), dan, karena memikirkan dirinya sendiri, memancarkan lingkaran langit ketiga, tempat beradanya bola Saturnus (kurrat al-Zuhal). Akal IV, karena memikirkan Tuhan, memancarkan Akal V (wujud VI), dan, karena memikirkan dirinya sendiri, memancarkan langit keempat, tempat beradanya bola Yupiter (kurrat al-Musytari). Akal V, karena memikirkan Tuhan, memancarkan Akal VI (wujud VII), dan, karena memikirkan dirinya sendiri, memancarkan langit kelima, tempat beradanya bola Mars (kurrat al-Mirrikh). Akal VI, karena memikirkan Tuhan, memancarkan Akal VII (wujud VIII), dan, karena memikirkan dirinya sendiri, memancarkan langit keenam, tempat beradanya bola matahari (kurrat al-Syams). Akal VII, karena memikirkan Tuhan, memancarkan Akal VIII (wujud IX), dan, karena memancarkan dirinya sendiri, memancarkan langit ketujuh, tempat beradanya bola Venus (kurrat al-Zahrah). Akal VIII, karena memikirkan Tuhan, memancarkan Akal IX, dan, karena memikirkan dirinya sendiri, memancarkan langit kedelapan, tempat beradanya bola Merkuri (kurrat al-Ataarid). Akal IX, karena memikirkan Tuhan, memancarkan Akal X, dan, karena memikirkan dirinya sendiri, memancarkan langit kesembilan, tempat beradanya bola Bulan (kurrat al-Qamar). Akal X, karena memikirkan Tuhan dan dirinya, hanya memancarkan bumi dan jiwa yang berda di lingkungan bumi. ${ }^{10}$

Akal I sampai dengan Akal X disebut juga oleh Al-Farabi dengan sebutan al-asy-ya' al-mufariqah (sesuatu yang terpisah dari materi, atau sesuatu yang imateri/rohani), yang pada hakikatnya adalah akal-akal dan sekaligus ma'qulat (obyek-obyek pemikiran). Bagi Al-Farabi, para malaikat itu tidak lain dari akal yang sepuluh itu, sedang Akal X, yang disebutnya juga Al-'Aql al-fa' 'aal (Akal Aktif) adalah Jibril a.s.

\section{Filsafat Jiwa}

Al-Farabi berupaya membuat sintesa antara pandangan Plato dan pandangan Aristoteles, tentang jiwa manusia. Mengikuti pandangan Aristoteles, Al-Farabi menyatakan bahwa jiwa manusia adalah bentuk (surah/form) bagi tubuhnya, tapi tidak sekedar itu karena ia juga mengikuti Plato yang mengatakan bahwa jiwa manusia itu adalah substansi imateri yang tidak hancur dengan hancurnya badan. Berbeda dengan Plato, Al-Farabi tidak mengakui pra-eksistensi jiwa manusia. Bagi Al-Farabi, jiwa manusia itu dipancarkan oleh Akal X manakala suatu tubuh sudah siap untuk menerimanya. Ia juga mengingkari

\footnotetext{
${ }^{10}$ Muhammad Hasbi, Pemikiran Emanasi Dalam Filsafat Islam, (Journal Al-FIKR, Vol. 3 Tahun 2010), 365 .
} 
reinkarnasi jiwa (perpindahan jiwa secara berulang-ulang dari satu tubuh kepada tubuh yang lain). Demikianlah pandangan Al-Farabi tentang jiwa manusia: tidak sepenuhnya mengikuti Plato, dan tidak sepenuhnya mengikuti Aristoteles. ${ }^{11}$

Mengenai potensi-potensi yang dimiliki oleh jiwa manusia, tampak bahwa pandagan Al-Farabi mengikuti pandangan Aristoteles. Al-Farabi dalam salah satu bukunya menerangkan sebagai berikut. Bila telah tercipta seorang manusia, maka yang pertama mengaktual pada jiwanya adalah potensi makan (al-quwwah algaziyah), kemudian potensi mengindra (al-quwwah al-hassah)untuk mengindra apa yang bisa diindra (panas, dingin, rasa makanan, bau, suara, dan lain-lain) dan bersamaan dengan itu mengaktual kecenderungan ( $a l$-nuzu') untuk menyenangi atau membenci apa yang diindranya. Kemudian mengaktual potensi mengkhayal (al-quwwa al-mutakhayyilah) untuk memelihara atau menyimpan gambargambarfenomena yang telah dihasilkan oleh pengindraan, menghimpun dan memisahkan satu bagian dengan bagian yang lainsehingga terbentuk susunansusunan atau klasifikasi-klasifikasi yang berbeda-beda, yang sebagian bisa benar dan bisa salah, dan bersamaan dengan itu juga mengaktual kecenderungan untuk senang atau benci pada apa yang dihasilkan aktualitas potensi menghayal itu. ${ }^{12}$

Pada tulisannya yang lain Al-Farabi menerangkan bahwa setiap spesies tumbuhan memiliki jiwa; demikian pula binatang dan manusia. Jiwa manusia memiliki potensi-potensi yang dapat mengaktual menjadi daya-daya untuk mewujudkan perbuatan-perbuatan melalui alat-alat tubuh, seperti yang dimiliki oleh jiwa tumbuhan dan binatang, dan mempunyai kelebihan dari jiwa binatang, yaitu memiliki potensi yang dapat mengaktual menjadi daya untuk berbuat, tapi tidak dengan alat tubuh; dan itulah potensi akal (quwwat al- 'aqi). Potensi-potensi jenis pertama (untuk mewujudkan perbuatan melalui alat tubuh) adalah potensi makan (al-gaziyah), potensi pemelihara (al-murobbiyah), potensi mengembangkan jenis (al-muwallidah) dan lain-lain. ${ }^{13}$

Semua potensi-potensi tersebut dapat mengaktual dan digunakan melalui alat tubuh dan tidak mungkin tanpa tubuh karena tak satupun aktualitasnya lepas dari materi. Potensi yang hanya dimiliki oleh jiwa manusia, tidak dimiliki jiwa binatang dan tumbuhan, adalah potensi akal praktis (al-aql al-'amali) untuk memikirkan apa yang wajib dilakukan manusia, dan potensi akal teoritis (al-'aql

\footnotetext{
${ }^{11}$ Haidar Bagir, Buku Saku Filsafat, (Bandung: Mizan 2006), 15.

${ }^{12}$ Ibrahim Madkur, Fi Al-Falsafah al-Islamiah Manhaj wa Tatbiquh, diterjemahkan oleh Yulian Wahyudi Asmin \& A. Hakim Mudzakir dengan Judul Falsafat Islam, Metode dan Penerapan (Jakarta: Raja Grafindo Persada Pers, 1993), 227.

${ }^{13}$ M. M. Syarif, History of Muslim Philisophy, penyunting Ilyas Hasan, Para Filosof Muslim, (Bandung: Mizan, 1994), 70.
} 
al-nazari atau al- 'aql al-'ilmi). Bila potensi yang akhir ini mengaktual pada jiwa manusia, maka jiwa manusia menjadi sempurna dan substansinya mengaktual menjadi substansi rasional secara aktaul. Potensi akal teoritis adalah potensi untuk melepaskan arti-arti atau bentuk-bentuk dari materinya, dan bila potensi akal itu yang disebut juga akal material (al-aql al-hayuulaani) mengaktual menjadi akal aktual (al-aql bi al-fi'l), maka jadilah bentuk-bentuk atau arti-arti yang dilepaskan dari materinya itu berubah pula dari potensial menjadi aktual masih bisa meningkat lagi menjadi jiwa dengan akal perolehan (al-'aql al-mustafad). Bila jiwa dengan akal aktual hanya dapat menangkap arti-arti yang dilepaskan materi (al-ma;quulaat al-mujarrodah), maka jiwa dan akal perolehan sanggup menangkap bentuk-bentuk murni/semata (al-suwar al-mujarradah), yakni bentukbentuk yang tidak berasal dari substansi materi, tapi dari substnsi-substansi dari imateri, seperti akal X sampai dengan akal I, dan Tuhan. Jiwa dengan akal perolehan adalah jiwa yang mampu berkomunikasi dengan Akal Aktif (Akal X/Jibril). Peran Akal Aktif terhadap jiwa manusia adalah seperti peran matahari terhadap mata. Karena mendapat sinar dari Akal Aktif, maka jiwa manusia yang sudah sampai tahap memperoleh akal perolehan, dapat menangkap arti-arti atau bentuk-bentuk murni tersebut. ${ }^{14}$

Bila akal teoritis telah ada secara aktual pada jiwa seseorang, maka berarti ia sudah memiliki kesempurnaan tingkat pertama sebagai manusia. Manusia pada umumnya dapat mencapai kesempurnaan tingkat pertama ini. Kesempurnaan tingkat kedua (tertinggi) tercapai bila jiwanya memperoleh akal mustafad. Mayoritas manusia tidak berhasil mengaktualkan akal mustafad pada jiwa mereka. Siapa yang berharap atau berkeinginan mengaktualkan akal mustafad pada jiwanya, haruslah lebih dahulu berupaya keras menjalani hidup zuhud (menjauhkan diri mengejar kesenangan materi/fisik), dan berupaya keras menguasai sebanyak mungkin bentuk-bentuk atau arti-arti yang dilepaskan dari materi. Bila ini telah dicapai, maka berarti jiwanya sudah berada dalam taraf siap menerima bentuk-bentuk murni (ide-ide nin-saintifik) atau akal mustafad yang dilimpahkan oleh Akal Aktif. Mereka yang memperoleh akal mustafad itu disebut sebagai para filosof. ${ }^{15}$

\section{Falsafat Kenabian}

Sebagai seorang filosof Muslim, Al-Farabi melawan pandangan yang menafikan (meniadakan) kenabian. Ia adalah seorang nasionalis, tapi bukan

\footnotetext{
${ }^{14}$ Harun Nasution, Falsafat dan Mistisisme dalam Islam, (Jakarta: Bulan bintang, 1992), 29.

${ }^{15}$ Muhammad Al-Baha, Al-Janib al-Ilahy Min al-Tafkir al-Islamy, (Mesir: Dar al-Kutub al'Arabiy, 1977), 377.
} 
rasionalis yang mengingkari adanya wahyu Tuhan. Sejalan dengan pandangan segenap ulama /umat Islam, Al-Farabi menunjukkan bahwa kenabian itu adalah suatu yang diperoleh manusia utama, yang disebut nabi/rasul, bukan melalui upaya mereka. Ajaran yang diwahyukan Tuhan kepada para nabi bukanlah diperoleh mereka melalui upaya keras mereka membersihkan jiwa mereka atau melalui upaya keras menguasai sebanyak mungkin ide-ide saintifik. Jiwa para nabi tanpa dilatih untuk membersihkan diri dan tanpa dilatih berfikir seperti calon filosof, telah berada dalam kondisi siap menerima ide-ide atau ajaran-ajaran yang diwahyukan Tuhan melalui Ruh al-Quds atau Akal Aktif. ${ }^{16}$

Dalam salah satu tulisannya, Al-Farabi menyatakan bahwa seyogianya dimaklumi bahwa alam tidak berbuat secara sia-sia, maka apalagi penciptanya, yakni Tuhan. Sebagai pemberi ikhtiar dan daya pikir pada manusia, Ia tidak mungkin mengabaikan urusan-Nya, dan adalah wajib-sebagai manifestasi keadilan-Nya- Ia menunjukkan jalan bagi umat manusia dan karena tidak mungkin Ia mengutus orang yang sama tabiatnya dengan mereka karena mereka tentu tidak sanggup memahami apa yang disampaikan oleh utusan yang tidak setabiat dengan mereka. Argument lain yang diberikan oleh Al-Farabi tentang adanya Nabi/rasul adalah kenyataan bahwa pada umat manusia, akal dan potensipotensi jiwa mereka, terdapat perbedaan keunggulan dalam aktualitas, seperti kenyataan, bahwa seorang mengungguli segenap manusia lainnya dalam satu bidang seni. Dengan demikian, tidak mustahil benar bahwa pada umat manusia ini terdapat orang yang hatinya mampu menerima wahyu, sedangkan orang lain tidak sanggup, dan dengan keunggulannya itu ia memikul tugas menyampaikan ajaran Tuhan yang diwahyukan kepadanya, menggariskan hukum-hukum, dan menunjukkan jalan-jalan yang menuju kepada kemaslahatan makhluk, dan wajiblah bagi setiap orang yang mentaatinya. ${ }^{17}$

Selanjutnya, menurut Al-Farabi, Nabi adalah manusia yang memiliki daya mengkhayal (al-mutakhayyilah-dengan fungsi menerima informasi dari daya indra, mengolahnya, dan kemudian menyampaikannya kepda daya pikir) yang luar biasa kemampuannya. Meskipun tetap menjalankan fungsinya yang lazim, daya luar biasa itu masih memiliki banyak daya untuk berhubungan dengan Akal Aktif (Akal X/Jibril). Dengan daya luar biasa itu, seorang Nabi menerima wahyu atau ajaran agama dari Tuhan melalui Akal Aktif. Dalam salah satu tulisannya,

\footnotetext{
${ }^{16}$ Qosim Nursh eha Dzulhadi, Al-Farabi dan Filsafat Kenabian, (Journal Kalimah, Vol. 12, No. 1 Maret 2014), 124-125.

${ }^{17}$ Amin Abdullah, "Aspek Epistemologis Filsafat Islam." (Makalah Diskusi Yogyakarta, 1992), 16.
} 
Al-Farabi menyatakan bahwa tidak mustahil bagi seorang (Nabi) bila daya mutakhayyalah-nya mencapai puncak kesempurnaan aktualitas, untuk menerima di kala sadar (bukan tidur) dari Akal Aktif ide-ide tentang peristiwa-peristiwa yang terjadi sekarang atau pada masa mendatang, dan menerima ide-ide tentang wujud imateri dan wujud mulia lainnya, serta melihatnya dan jadilah ide-ide yang diterimanya itu sebagai nubuwwah (berita Ilahi) tentang hal-hal yang bersifat Ilahi. Al-Farabi juga menyatakan bahwa Nabi itu memiliki jiwa dengan daya yang kudus (suci) sehingga kepada jiwanya yang kudus itu tunduk daya alam makro seperti tunduknya daya alam mikro (raga seseorang) kepada jiwanya. Dengan daya yang kudus itu, jiwa Nabi dapat melakukan peristiwa-peristiwa luar biasa atau mukjizat. ${ }^{18}$

Dengan mengajukan teori tentang Nabi dan filosof yang sama-sama berkomunikasi dengan Akal Aktif, dapat dipahami bahwa Al-Farabi telah menunjukkan sumber ajaran agama yang dibawa Nabi dan falsafat yang dihasilkan filosof adalah sama (Akal Aktif), dan karena itu kebenaran keduanya pastilah tidak bertentangan. Dengan mengajukkan bahwa Nabi memiliki jiwa dengan daya kudus (kendati pada daya mutakhayyalah-nya) sehingga tidak perlu berlatih/berupaya keras untuk membersihkan jiwa (seperti yang dilakukan calon sufi) atau untuk menguasai ide-ide saintifik (seperti yang dilakukan calon filosof), Al-Farabi juga telah menunjukkan keistimewaan/kelebihan nabi daripada filosof, dan bukan sebaliknya. ${ }^{19}$

\section{Hidup Sesudah Mati}

Mengenai hidup sesudah mati, yakni hidupnya di akhirat, Al-Farabi, seperti Al-Kindi, memiliki pandangan bahwa kehidupan manusia di akhirat adalah bersifat rohaniah, tanpa jasmani. Bagi Al-Farabi, manusia pada hakikatnya adalah jiwanya, bukan tubuhnya, dan yang pantas disebut jiwa manusia adalah jiwa yang sudah memiliki akal praktis dan teoritis secara aktual. Bila belum dimiliki secara aktual, maka jiwa itu belum dapat disebut jiwa manusia, dan itu berarti masih sama saja dengan jiwa binatang. Bagi Al-Farabi, hanya jiwa manusia yang mengalami kekekalan di akhirat, baik dalam kebahagiaan maupun dalam adzab penderitaan. Jiwa yang pernah hidup pada tubuh manusia, tapi tidak mengaktual padanya akal praktis dan teoritis, akan hancur bersama hancurnya badan. ${ }^{20}$ Kebahagiaan jiwa manusia setelah berpisahnya dari badan, tidaklah sama

\footnotetext{
No.1, 2014)

${ }^{18}$ Qosim Nursheha Dzulhadi, "Al-Farabi dan Filsafat Kenabian. (Jurnal Kalimah, Vol. 12,

${ }^{19}$ Al-Farabi, Ihshā'ul 'Ulūm, (Beirut: Inmaul Qaumiy, tt), 20.

${ }^{20}$ Al-Farabi, Tahshīlus Sa'ādat, tahqiq Alibu Mulham (Beirut: Daar al-Hilal, 1995), 20.
} 
antara satu dengan yang lain, demikian pula dengan kesengsaraannya. Kualitas jiwa manusia itu berbeda-beda, dan demikian mestilah, berdasarkan prinsip keadilan, kebahagiaan atau kesengsaraan yang dialami jiwa manusia itu sesuai dengan kualitas kesucian atau keutamaan jiwa manusia itu sendiri. Urusan mencocokkan itu berada di tangan Tuhan, kata Al-Farabi.

Menurut Al-Farabi jiwa-jiwa yang kekal dalam kebahagiaan akhirat itu ialah jiwa-jiwa penduduk kota utama, dan itulah jiwa-jiwa utama, yang mengetahui kebenaran, keutamaan, dan kebahagiaan sejati, serta setia mengerjakan perbuatan-perbuatan baik, dan dengan demikian jiwa-jiwa tersebut menjadi kuat dan sempurna, atau sampai kepada taraf tidak merasa butuh lagi kepada materi. Adapun jiwa-jiwa yang kekal dalam kesengsaraan di akhirat ialah jiwa-jiwa yang durhaka (fasiq). Jiwa-jiwa tersebut mengetahui kebenaran, baik dan buruk, serta kebahagiaan sejati, tapi mereka berpaling dari keutamaan. Mereka melakukan perbuatan-perbuatan yang rendah dan tetap teperdaya oleh kesenangan-kesenangan jasmaniah yang rendah. Setelah badan mengalami kematian/hancur, maka jiwa-jiwa yang durhaka ini terus hidup kekal dalam kekecewaan atau kesengsaraan. Jiwa-jiwa jaahilah (bodoh) dalam arti tidak mengaktual akal praktis dan teoritis pada mereka, hancur bersama hancurnya badan. Sebagaimana telah disinggung, bagi Al-Farabi tidak ada pra-eksistensi jiwa, dan tidak ada pula reinkarnasi jiwa. Hidup jiwa dalam badan manusia hanya sekali, dan setelah itu jiwa hidup tanpa badan, dalam kebahagiaan atau dalam kesengsaraan. $^{21}$

\section{Karya-Karya Al-Farabi}

Al-Farabi mendapatkan gelar kehormatan sebagai guru kedua dengan catatan bahwa gelar guru pertama dialamatkan orang pada Aristoteles. Besar dugaan bahwa gelar kehormatan itu diberikan berdasarkan penilaian dan pengakuan bahwa ia adalah tokoh paling terkemuka setelah Aristoteles dalam lapangan logika. Ia tidak saja menguasai logika dengan baik melainkan juga pemikiran filsafat pada umumnya. Pemahaman atau pemikirannya cermat, mendalam, matang, dan sistematis, dan berkat tulisannyalah Al-Farabi dapat mengatasi kesulitan dalam memahami metafisika Aristoteles. ${ }^{22}$ Al-Farabi meninggalkan sejumlah besar karya-karya tulis yang penting, kendati dalam bilangan tidak sebanyak yang dihasilkan Al-Kindi atau oleh Al-Razi. Jumlah karya tulisnya menurut Qifti atau Ibnu Abi Usaibi'ah, lebih kurang 70 buah, yang

\footnotetext{
${ }^{21}$ Abdul Aziz Dahlan. Pemikiran Falsafi Dalam Islam, (Jakarta: Karya Unipress, 2003).

${ }^{22}$ Hasan Hanafi, Al-Farabi Syarih Aristo, dalam Abu Nashr al-Farabi: Fi Dzikra Alfiah li Wafatih, (Kairo: al-Hai'ah al-Mashriyah al-Ammah, 1983), 69.
} 
dapat dibagi menjadi dua kelompok: kelompok yang berkaitan dengan logika dan kelompok yang berkaitan dengan berbagai cabang ilmu dan falsafat, seperti fisika, matematika, metafisika, etika, dan politik.

Sebagian besar dari karya tulisnya telah hilang atau belum ditemukan. Karya tulisnya yang sudah ditemukan, sebagian sudah diterbitkan dan sebagian lagi masih dalam bentuk manuskrip. Di antara karya tulisnya itu ialah: Kitab Ara Ahl al-Madinah al-Fadilah (tentang pandangang-pandangan penduduk kota utama), Kitab Ihsa al-Ulum (tentang perincian pengetahuan), Risalah fi al-Aql (tentang akal), Risalah fi Isbat al-Mufariqar (tentang wujud-wujud rohaniah), Tahsil as-Sa'adah (tentang upaya mewujudkan kebahagiaan), Masail Falsafiyyah wa Ajwibah 'anha (tentang masalah-masalah falsafat dan jawabannya), AlIbaanah 'an Gard Aristutalis (tentang pemikiran Aristoteles), dan Kitaab Bayn Aflaatun wa Aristu aw al-Jam' Bayn Ra'yayn al-Hakimayn (tentang persesuaian pendapat Plato dengan Aristoteles). Melalui karya-karya tulisnya itu, Al-Farabi memperlihatkan dirinya sebagai Muslim yang teguh memegang agama, penerus Plato dalam bidang etika, dan politik, penerus Aristoteles dalam bidang logika dan fisika, dan sebagai pengikut Plotinus dalam bidang metafisika. Dari berbagai sumber itu ia memperoleh prinsip-prinsip yang diyakininya serasi sehingga ia dapat membangun satu sistem falsafat yang lengkap.

\section{Meninjau Konsep Dasar Pemikiran Filsafat Ibnu Sina}

\section{Wajib al-Wujud dan Mukmin al-Wujud}

Ibnu Sina dalam tulisannya berupaya menjelaskan pengertian wajib alwujud (yang mesti ada) dan mukmin al-wujud (yang boleh ada). Wajib al-wujud adalah wujud yang menurut akal mestilah ada, dan mustahil tidak ada; sedang mukmin al-wujud adalah wujud yang menurut akal tidak mesti ada, tidak mesti tidak ada (tidak mustahil ada), tapi boleh ada dan boleh pula tidak ada. Wajib alwujud dapat pula dibagi dua kategori, yaitu: wajib al-wujud zatih (yang mesti ada dan mesti selamanya ada karena dirinya sendiri) dan wajib al-wujudbi gayrih (yang mesti ada karen yang lain). Yang akhir ini (wajib al-wujud bi gayrih,; yang mesti ada karena yang lain) mestilah ada bila yang lain ada; tapi bila yang lain tidak ada, ia tidak mesti ada karena ia sebenarnya juga adalah mukmin al-wujud bi zaatih (wujud yang diliha dari sudut dirinya boleh ada, boleh tidak ada, tidak mesti ada, tidak mesti tidak ada, atau tidak mustahil ada). Sebagai contoh, bila ada 
dua dan tiga, maka mestilah ada lima karena adanya dua dan tiga itu. Bila dua dan tiga tidak ada, maka lima tidak mesti ada. ${ }^{23}$

Wajib al-wujud karena dirinya sendiri tidak bisa sesuatu himpunan, dan tidak bisa sesuatu yang mengandung bagian-bagian atau mengandung kejamakan. Ia haruslah sesuatu yang simpel, kebaikan yang sempurna, dan tidak bersifat materi/potensi. Ia sepenuhnya 'aqil (yang berpikir), 'aql (daya pikir), dan $m a$ 'qul (yang dipikirkan) sekaligus. Ia haruslah kebenaran semata (absolut) dan esa hakiki (absolut). Iradahnya tidaklah berbeda dari ilmunya, dan tidak berbeda dari kekuasaanya. Semua sifat-sifatnya atau salah satu sifatnya tidak memestikan adanya kejamakan dan keberlainan pada dirinya. Wajib al-wujud karena dirinya sendiri itu tidak lain dari Allah swt. Sedangkan wajib al-wujud karena yang lain, atau mukmin al-wujud karena dirinya sendiri, tidaklah lain dari segenap alam yang diciptakan Tuhan.

\section{Qodim dan Muhdas}

Ibnu Sina dalam tulisannya berupaya menjelaskan pengertian qadim (sesuatu yang tidak ada awalnya) dan muhdas (sesuatu yang dijadikan/diciptakan). Menurutnya ada dua macam qadim, yaitu qadim dari segi substansi dan qadim dari segi waktu. Qadim dari segi substansi berarti substansinya itu ada dengan sendirinya, tidak bersal dari substansi yang lain, Qodim dari segi waktu berarti substansinya tidak pernah tidak ada di masa lalu, atau tidak di dahului oleh waktu. Muhdas juga dua macamnya, yaitu Muhdasdari segi substansi dan muhdas, dari segi waktu. Muhdas dari segi substansi berarti substansinya diciptakan atau keberadaan substansinya bergantung pada substansi yang lain. Muhdas, dari segi waktu berarti suatu yang pernah tidak ada dan kemudian ada karena diciptakan/diwujudkan, atau dengan kata lain: pada awalnya ia tidak ada, kemudian ada. Menurut Ibnu Sina, seperti menurut Al-Farabi juga, Tuhan adalah satu-satunya wujud yang qadim dari segi substansi dan dari segi waktu, sedang totalitas alam ciptaan-Nya adalah muhadas dari segi substansi, tapi qadim dari segi waktu. Itu berarti bahwa totalitas alam, substansinya bukanlah ada dengan sendirinya, tapi bergantung pada substansi Tuhan, adanya karena diciptakan Tuhan; kendati demikian, penciptaannya berlangsung sejak qadim, sehingga dari segi waktu-alam, yang diciptakan itu juga qadim. Ibnu Sina menegaskan bahwa penciptaan alam itu berlangsung sepanjang masa (terus menerus), dan tidak mungkin bahwa alam itu muncul sesudah pernah ia tidak ada.

\footnotetext{
${ }^{23}$ Syarif, M. M.. Para Filosof Muslim. Cet. ke-2. (Bandung: Mizan, 1998).
} 
Kemunculannya mustahil tdak didahului oleh materi/potensi yang darinya alam itu muncul/dijadikan. ${ }^{24}$

\section{Teori Emanasi}

Dalam teori emanasi Ibnu Sina hampir tidak berbeda sama sekali dengan teori emanasi yang telah lebih dahulu dikemukakan Al-Farabi. Dari Tuhan memancar 10 akal (Akal I sampai dengan akal X), 10 jiwa (9 jiwa langit dan satu jiwa bumi), dan 10 raga ( 9 raga langit dan satu raga bumi). Emanasi itu adalah akibat aktivitas mengetahui atau berpikir. Tuhan berpikir tentang diri-Nya, maka memancar Akal I. Akal I memiliki tiga aktivitas berpikir, yaitu: (i) berpikir tentang Tuhan, (ii) berpikir tentang dirinya sebagai wajib al-wujud karena Tuhan, dan (iii) berpikir tentang dirinya sebagai mukmin wujud dari segi substansi sendiri. ${ }^{25}$ Sebagai akibat aktivitas pertama, memancar Akal II; sebagai akibat aktivitas kedua, memancar jiwa langit pertama; dan sebagai akibat aktivitas ketiga, memancar raga langit pertama. Akal II juga memiliki tiga aktivitas seperti tersebut di atas, dan akibatnya juga tiga, yaitu meuncul Akal III, jiwa langit kedua, dan raga langit kedua. Demikian seterusnya sampai muncul Akal X, jiwa langit kesembilan (bulan), dan raganya. Dari Akal X hanya memancar jiwa dan raga bumi. Akal IX tidak cukup kuat untuk memancarkan Akal berikutnya. Pada bumi banyak muncul raga-raga tumbuhan, binatang, dan manusia, yang masingmasing raga itu ditempati oleh satu jiwa individual. ${ }^{26}$

\section{Tuhan, Akal, Jiwa, dan Tubuh.}

Baik Tuhan, maupun akal-akal ('uqul), dan jiwa-jiwa (nufus) adalah substansi-substansi yang imateri. Tuhan dan akal-akal, selain imateri, juga selamanya terpisah dari materi/tubuh. Tuhan mengatur segenap alam melalui akal-akal. Akal-akal adalah pengatur materi/tubuh secara tidak langsung, sedang yang langsung mengatur/mengendalikan materi/tubuh. Dalam pemahaman Ibnu Sina, Akal I adalah pengatur raga langit pertama secara tidak langsung. Pengaturnya langsung adalah jiwa langit pertama itu sendiri. Akal II adalah pengatur tidak langsung terhadap raga langit kedua, sedang pengatur terhadap raga langit kedua adalah jiwa langit kedua itu sendiri. Demikianlah seterusnya dengan akal-akal berikutnya. Akal $\mathrm{X}$ adalah pengatur tidak langsungterhadap raga-raga yang terdapat di bumi, tapi pengendali masing-masing raga itu secara

\footnotetext{
${ }^{24}$ Herwansyah, Pemikiran Filsafat Ibnu Sina: Filsafat Emanasi, Jiwa, dan Al-Wujud, (Journal El-Fikr, Vol. 1, No. 1, Tahun 2017). 56.

${ }^{25}$ Al-Fukhury, Hana dan Khalil Al-Jarr. Tarikh Al-Falsafah Al-Arabiyah, (Mulasassat Li AlThaba"eah. Bairut, 1963).

${ }^{26}$ Daudy, Ahmad. Kuliah Filsafat Islam. (Jakarta: Bulan Bintang, 1989).
} 
langsungadalah jiwa masing-masing. Manusia, misalnya sebagai makhluk yang terdiri dari tubuh dan jiwa rasional, maka yang diminta pertanggungjawaban aktivitasnya adalah jiwanya, karena jiwanya itulah menjadi pengendali langsung terhadap tubuhnya. Tuhan dan Akal X hanyalah pengendali/pengatur secara tidak langsung terhadap tubuh manusia. Akal $X$ yang berhubungan langsung dengan jiwa-jiwa di bumi, termasung dengan jiwa-jiwa manusia, disebut dalam falsafah Ibnu Sina sebagai Akal Aktif, yang menggerakkan sesuatu yang potensil di bumi menjadi sesuatu yang aktual. ${ }^{27}$

\section{Penutup}

Dari pembahasan tersebut bisa kita tarik kesimpulan bahwa dua orang filosof ternama dunia Al-Farabi dan Ibnu Sina adalah yang membawa tonggak-tonggak filsafat Islam yang kemudian diikuti oleh para filosof setelahnya. Dari karya-karya merekalah sehingga membuat dunia tercerahkan baik dalam bidang kedokteran maupun dalam bidang keilmuan yang lain seperti filsafat emanasi dan jiwa yang telah penulis sebutkan dalam pembahasan tersebut. Al-Farabi dan Ibnu Sina menjadi ujung tombak bagi generasi Islam setelahnya, dari merekalah generasi Islam belajar banyak hal tentang filsafat Islam. Sekalipun masih banyak yang diperdebatkan oleh para ulama dan generasi Islam tentang isi pikiran-pikiran kedua filosof tersebut. Tetapi pada dasarnya mereka telah memberikan kontribusi yang terbaik lewat keilmuankeilmuannya pada Islam khususnya dan dunia luar pada umumnya.

\section{DAFTAR PUSTAKA}

Abdullah, Amin. Aspek Epistemologis Filsafat Islam. Makalah Diskusi Yogyakarta, 1992.

Al-Ahwani, Ahmad Fuad. Filsafat Islam. Jakarta: Pustaka Firdaus, 1997.

Al-Baha,Muhammad. Al-Janib al-Ilahy Min al-Tafkir al-Islamy. Mesir: Dar al-Kutub al-'Arabiy, 1977.

Al-Farabi. Kitab al-Jam’ baina Ra'yain al-Hakimaini. Beirut: Dar al-Masriq, Beirut.

Al-Farabi, Ihshā'ul 'Ulūm. Beirut: Inmaul Qaumiy, tt.

Al-Farabi, Tahshīlus Sa'ādat, tahqiq Alibu Mulham. Beirut: Daar al-Hilal, 1995.

Al-Fukhury, dkk. Tarikh Al-Falsafah Al-Arabiyah. Mulasassat Li Al-Thaba ah. Bairut, 1963.

Bagir,Haidar.Buku Saku Filsafat. Bandung: Mizan 2006.

\footnotetext{
${ }^{27}$ Kamil, Muhammad. Ibnu Sina Hayatuhu Atsaruhu Wa Filsafatuhu, Dar Al-Kutub AlIlmiyah, Bairut. 1991.
} 
Dahlan, Abdul Aziz. Pemikiran Falsafi Dalam Islam. Jakarta: Karya Unipress, 2003.

Daudy, Ahmad. Kuliah Filsafat Islam.Jakarta: Bulan Bintang, 1989.

Dzulhadi,Qosim Nursheha.“Al-Farabi dan Filsafat Kenabian”, Journal Kalimah, Vol. 12, No. 1 Maret 2014.

Hanafi,Hasan.Al-Farabi Syarih Aristo, dalam Abu Nashr al-Farabi: Fi Dzikra Alfiah li Wafatih. Kairo: al-Hai'ah al-Mashriyah al-Ammah, 1983.

Suprapto, Hadi. "Al-Farabi dan Ibnu Sina: Kajian Filsafat Emanasi dan Jiwa Dengan Pendekatan Psikologi”, Jurnal Al-Hadi, Vol. 2, No. 2, Januari-Juni 2017.

Hasbi, Muhammad."Pemikiran Emanasi Dalam Filsafat Islam”, Journal Al-FIKR, Vol. 3 Tahun 2010.

Herwansyah, "Pemikiran Filsafat Ibnu Sina: (Filsafat Emanasi, Jiwa, dan Al-Wujud), Journal El-Fikr, Vol. 1, No. 1, Tahun 2017.

Kamil, Muhammad. Ibnu Sina Hayatuhu Atsaruhu Wa Filsafatuhu, Dar Al-Kutub AlIlmiyah, Bairut. 1991.

Madkur, Ibrahim.Fi Al-Falsafah al-Islamiah Manhaj wa Tatbiquh, diterjemahkan oleh Yulian Wahyudi Asmin \& A. Hakim Mudzakir dengan Judul Falsafat Islam, Metode dan Penerapan. Jakarta: Raja Grafindo Persada Pers, 1993.

Nasution, Harun. Filsafat dan Mistisisme Dalam Islam. Jakarta: Bulan Bintang, cet. II, 1978.

Nasution, Harun. Falsafat dan Mistisisme dalam Islam. Jakarta: Bulan bintang, 1992.

Nur,Abdullah."Ibnu Sina: Pemikiran Filsafatnya Tentang Al-Fayd, Al-Nafs, AnNubuwwah, dan Al-Wujud", Journal Hunafa, Vol. 6, No. 1, April 2009.

Sukardi, Imam. Disertasi Pemikiran Politik Al-Farabi (Diskursus Kepemimpinan Negara). Jakarta:Disertasi, UIN SyarifHidayatullah Jakarta, 2008.

Syarif,M. M. History of Muslim Philisophy, penyunting Ilyas Hasan, Para Filosof Muslim. Bandung: Mizan, 1994.

Syarif, M. M.. Para Filosof Muslim. Cet. 2; Bandung: Mizan, 1998.

Wiyono, M. Pemikiran Filsafat Al-Farabi. Journal Substantia, Vol. 18, No. 1, April 2016.

Zayid, Sa'id. Abu Nashr Al-Farabi: Fi al-Dzikra al-Fiah li Wafaatih. Kairo: alHai'ah al-Mishriyah al-'Ammah li al-Kitab, 1993. 